\title{
Belt and Road Initiative (BRI) of China: Connecting the World for Sustainable Economic Development
}

\author{
Md Rasel $^{1 *}$, Gaili Jiao${ }^{1}$, Shaheen Yusufzada², Bouasone Chanthamith ${ }^{2}$, Ayrin Sultana ${ }^{3}$ \\ ${ }^{1}$ College of Commerce, Ningxia Vocational Technical College of Industry and Commerce, Yinchuan, China \\ ${ }^{2}$ School of Public Administration, Sichuan University, Chengdu, China \\ ${ }^{3}$ Department of Finance and Banking, Hajee Mohammad Danesh Science and Technology University, Dinajpur, Rangpur, Bangladesh \\ Email: *rasel.swufe@gmail.com
}

How to cite this paper: Rasel, M., Jiao, G., Yusufzada, S., Chanthamith, B. and Sultana, A. (2020) Belt and Road Initiative (BRI) of China: Connecting the World for Sustainable Economic Development. Open Journal of Social Sciences, 8, 109-120. https://doi.org/10.4236/jss.2020.81009

Received: November 21, 2019

Accepted: January 10, 2020

Published: January 13, 2020

Copyright $\odot 2020$ by author(s) and Scientific Research Publishing Inc. This work is licensed under the Creative Commons Attribution International License (CC BY 4.0).

http://creativecommons.org/licenses/by/4.0/

\begin{abstract}
The aim of this article is to assess the effect of strategies of Belt and Road Initiative (BRI) on sustainable economic development of member countries. This study is based on qualitative approach and secondary data. A number of documents such as journal articles, government reports, books, book chapters and working papers have been consulted to substantiate the arguments. The article explores that there is a potential effect of BRI on the sustainable economic development of its member countries. Some of the member countries are getting direct benefits from it and other countries are in the way of getting benefits through infrastructure development, trading, cultural exchanges and mutual political agreements. It is empowering a number of developing countries through economic development by linking economic corridors, seaport, roads and railway networks. This article also finds that so many economic zones are planned to open in member countries to get benefits from BRI initiative by promoting infrastructure, energy, gas, oil and electricity, roads, railways and other related projects.
\end{abstract}

\section{Keywords}

BRI, Foreign Direct Investment, Sustainable Development, Economic Corridor, Cultural Exchange

\section{Introduction}

China has taken a historical initiative entitled Belt and Road Initiative (BRI) for connecting the people across the world for sustainable economic development and progress in human civilization [1]. Belt and Road Initiative (BRI) is based 
on old Silk Road which already passed two thousand years and revival of the old Silk Road [2]. The spirit of the old Silk Road promotes present Chinese political leaders to initiate this BRI to promote global economic growth, regional and economic integration and global governance by understanding the mechanism of complex international politics [3].

The aim of the BRI is to connect Asia, Europe and Africa through strengthening partnerships among the countries [4]. China's imperial envoy Zhang Qian initiated the old silk road in 2000 years ago which has been facilitated as a trade route to Arab and central Asia [5]. Since silk was one of the topmost export items of china at that time so this route was known as Silk Road [6]. In 2013, president Xi Jinping declared to establish and revitalize the old Silk Road by establishing a connection among china, all parts of Asia, Europe and Africa through infrastructure development like railways and roads. It is the largest economic platform of the world which will promote global economic growth through strengthening economic cooperation [7]. BRI is working in two ways viz. Silk Road Economic Belt and $21^{\text {st }}$ Century Maritime Silk Road. The Silk Road Economic Belt consists of three routes which connects China to Europe, the Persian Gulf, the Mediterranean and the Indian Ocean. On the other hand, the $21^{\text {st }}$ Century Maritime Silk Road is based on waterways among BRI member countries. BRI is a mega project which covers two-thirds of the global population and three-fourth of the energy resources. Though some researchers thought that BRI is an initiative to promote their meltdown economy by creating smooth global markets [8]. It is portrayed to redesign the economic and political order of Asia by developing a network of cultural, political and trading corporations [9]. The BRI already got 65 countries as member under its initiative.

The importance of BRI initiative cannot be ignored due to its active role in mutual peace and economic development [10]. It connects Asian countries like Bangladesh, Brunei, Singapore, Sri Lanka, Cambodia, Myanmar, Maldives, Nepal, India, Sudan and Pakistan through seaports, oil and gas pipelines and economic corridors. It also finances for free trade economic zones and energy development projects in its member countries [11]. The policy makers and scholars of US, Japan and India expressed their security threats in the BRI regions due to the growing influence of BRI initiative of China [12]. Though China considered it as propaganda against BRI's peaceful journey. The benefit of the BRI will be available for all the people of the world due to its peaceful natures like mutual cooperation, integration and interdependence [13]. A multi-polar world will be established by proper implementation of BRI through trends of harmony and peace (Figure 1).

The Maritime Silk Road is connected to East-Asia, South-Asia, South-East Asia, and Africa through seaports. It starts from South-China sea like Fujian seaport, Qingdao seaport, Xin Gang seaport, Shanghai seaport, Hong-Kong Seaport and Ningbo seaport of China. These seaports are connected with other seaports of member countries. Chittagong port of Bangladesh, Muara seaport Brunei, Sihanoukville port of Cambodia, Hambantota port of Sri-Lanka, 


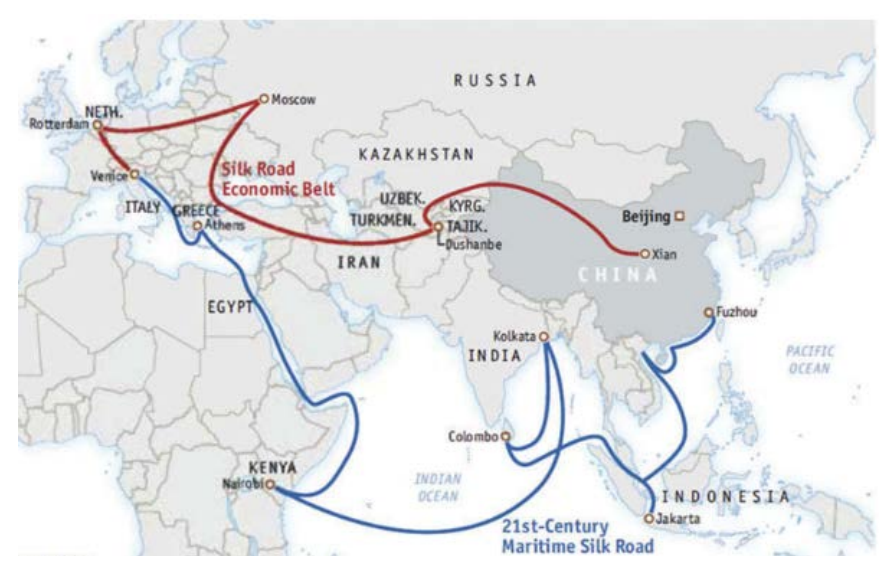

Figure 1. Map of the Belt and Road initiative of China. Source: Blanchard \& Flint (2017) [14].

Khaukpyu port of Myanmar, Maldives port, Sudan seaport, and Gwadar port of Pakistan are connected with Hong-Kong seaport and Ningbo seaports of the southern part of China. It also enters into Mediterranean Sea to connect economic belt at Venice, Italy [15]. So many small projects are being implemented under the main megaprojects for construction of the economic zones, seaports, gas and oil pipelines, roads, bridges, railways, canals and industrial zones for facilitating interconnection among distant regions of Asia, Europe and Africa [16]. So, it is a way to promoting economic development of some developing countries of Asia and Africa. Up to May, 2017 about 70 countries and international organizations already have signed for BRI initiative [17]. There are so many queries of people related to the projects under BRI since China is not willing to publish a complete list of projects. Up to 2013, about 50 Chinese SOC (state owned companies) have invested about 1700 small projects under BRI. Official Development Assistance (ODA) projects are designed to support for building infrastructure to member countries. China initiated Asian Infrastructure Investment Bank (AIIB) for providing investment support to BRI.

The main purpose of this study is to address the questions: 1) What are the smart objectives behind BRI initiative? 2) Are the strategies of BRI suitable for economic development of BRI regional countries? and 3) Will the member countries get benefit from BRI? These questions lead the researcher team to obtain the objective: to explore the SMART objectives and strategies of BRI for sustainable economic development of member countries. The first section describes about the introduction of BRI, second and third sections describes about methodology and systematic reviews of literature. Fourth and fifth section describes overview of BRI and strategy for sustainable economic development. Final section concludes the article with some recommendations.

\section{Methodology}

\subsection{Research Design}

A conceptual framework is developed on BRI initiative for economic develop- 
ment prospect for regional economic development through an extensive literature review [18]. It is descriptive in nature focusing key indicators of economic development. The study mainly focuses on economic context, strategy, opportunities and challenges of BRI initiatives on the basis of business, economic, political, social and environmental aspects.

\subsection{Sources of Data}

The study has been used secondary sources extensively related to implication of BRI initiative, challenges and opportunities in the process of implementation of BRI strategy and regional economic development. Some recommendations have been made for solving possible challenges of BRI initiative for regional economic development on the basis of latest information.

\subsection{Search Strategy}

Some renowned databases viz. Google Scholar, a web of science, Scopus, science direct, and Springer link website has been extensively searched by using important keywords like "one belt one road, economic belt, maritime silk road, BRI, economic development, policy, strategy, regional development, economic development, challenges, opportunities, security, geopolitics, and China for securing authentic information" [19]. The data collection and analysis for this study has been done considering the initiation period of One Belt One Road (OBOR) (Figure 2). According to Liu et al. [20], literature review is an important part of the expansion of a field. It provides an opportunity to make and reproduce the previous research, and thus giving safe grounding for the progress of knowledge [21].

\subsection{Data Analysis}

Finally, 97 documents are selected and analyzed from different perspectives of One Belt One Road, challenges and opportunities for implementation, funding sources, involvement of partner countries, suitability of economic corridors,

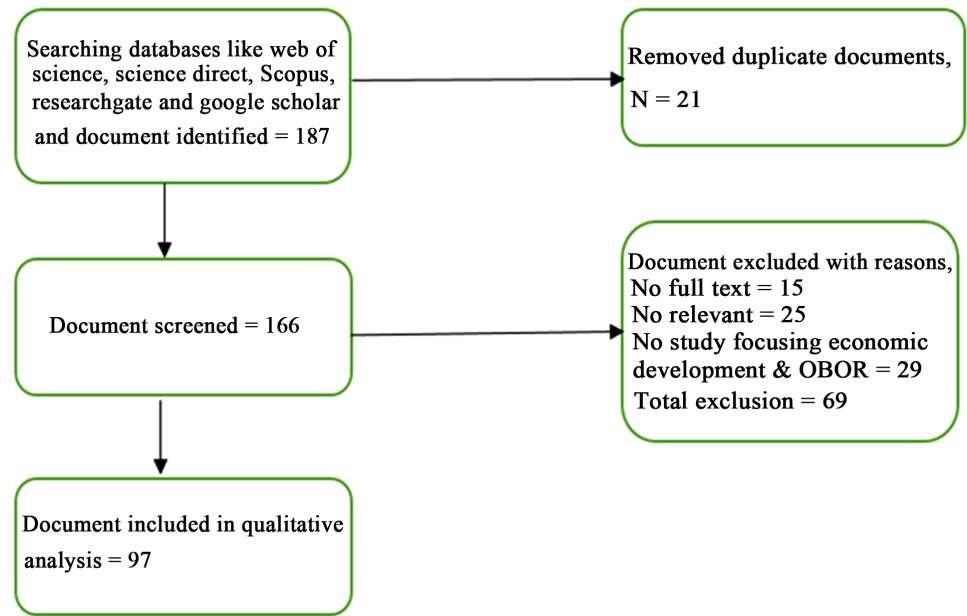

Figure 2. Document selection and analysis framework. 
strategy for implementation and regional economic development [22].

\section{Impact of BRI on Economic Development}

One Belt One Road (BRI) initiative is the most discussing topic to the economist. Some scholars are anxious about the economic impact of BRI initiative. Though it is the revival of old Silk Road but it has a great impact on global economy through integration of a large part of the world. It extends its opportunity through developing a historical infrastructural development [23]. It connects the world people through political, economic, and cultural exchanges [24]. Though some scholars think that BRI initiative is solely based on the implementation of Chinese "Go West" policy but still it has a tremendous impact on global economy. Chinese authority has a largest influence on BRI initiative because of an initiator and largest economy. It also included the Digital Silk Road initiative for connecting the world digitally which is administered by the Cyberspace Administration of China [16]. There is some geographically important place in China like Xinjiang as Core Area of the One Belt and Fujian as the "Core Area" for the "One Road" for implementing two mega projects under BRI initiative. Some other places like Qinghai, Gansu, Ningxia, and Shaanxi also important to connect China to central Asia through Economic Belt. The places like Sichuan, Chongqing, and Yunnan of China also connect China to Central, South, and Southeast Asia through Economic Belt while Southeast Asia, South Asia, the Middle East, and Africa through Fujian, Jiangsu, Zhejiang, Guangdong, and Hainan of China [25]. Some scholars mentioned that BRI initiative is the extension, enrichment, and amalgamation of some Chinese initiatives for promoting sluggish Chinese economy through maintaining national security, economic, business and international relations.

According to PWC [26], the BRI countries require at least USD 5 trillion for infrastructure development from 2016 to 2020 while according to Asian Development Bank, Asia require USD 8 trillion for infrastructure development by 2020 for connecting the partner of BRI countries and getting full benefit from BRI initiative. Since most of the BRI partners are developing countries so infrastructure development should be the top priority for global future development under BRI initiative [27]. Another most important step should be taken to remove the constraints of trade and investment, reducing trade cost and motivating economic development [28]. Financial integration is one of the important goals of BRI initiative which can be gained by encouraging monetary policy coordination, internalization of Renminbi (RMB) for trade and investment, motivating financial cooperation [29], creating regional financial institutions [30], strengthening cooperation for risk management [31], and encouraging regional mechanisms for managing financial risks [32] [33] [34]. Cultural exchanges can be happened through connecting people of BRI partner countries, enhancing mutual understanding and nurturing more interactions among people [35]. Proper implementation of BRI initiative can help to develop economy from China to central Asia, Europe and Africa [36] (Table 1). 
Table 1. Recent studies on the BRI initiative.

\begin{tabular}{|c|c|c|}
\hline Authors & Major issues/conclusions & Journal/sources \\
\hline David \& Liu (2017) [37] & $\begin{array}{l}\text { BRI of china may be a global connection economically or militarily } \\
\text { which has an economic effect on the partner region. }\end{array}$ & $\begin{array}{l}\text { International Relations } \\
\text { and Diplomacy }\end{array}$ \\
\hline Chung (2017) [38] & $\begin{array}{l}\text { BRI enhances the economic development that reinforces } \\
\text { its domestic political firmness in China and other partner countries. }\end{array}$ & The Pacific Review \\
\hline Haiquan (2017) [39] & BRI is a tool for developing China's open economy. & $\begin{array}{l}\text { Croatian International } \\
\text { Relations Review }\end{array}$ \\
\hline Zeng (2017) [40] & Europe contributes a relegated role in China's policy dialogue. & $\begin{array}{l}\text { Journal of Common } \\
\text { Market Studies }\end{array}$ \\
\hline Cheong (2017) [3] & $\begin{array}{l}\text { Focusing on economic valuation of BRI and some risks } \\
\text { concerning execution. }\end{array}$ & $\begin{array}{l}\text { Journal of International } \\
\text { Logistics and Trade }\end{array}$ \\
\hline Blanchard \& Flint (2017) [14] & $\begin{array}{l}\text { Major consideration of BRI are changing of global political } \\
\text { paradigm and solving practical problems. }\end{array}$ & Geopolitics \\
\hline Das (2017) [41] & $\begin{array}{l}\text { BRI can resolve the problem of excess production capacity } \\
\text { by exporting to the BRI geographical region. }\end{array}$ & China Report \\
\hline Du \& Zhang (2017) [42] & $\begin{array}{l}\text { Overseas direct investment (ODI) of China increased } \\
\text { significantly to the BRI countries. }\end{array}$ & China Economic Review \\
\hline Vangeli (2017) [43] & $\begin{array}{l}\text { BRI is the strong practical and normative link between China's } \\
\text { domestic development and its global orientation. }\end{array}$ & China \& World Economy \\
\hline Gabuev (2017) [44] & $\begin{array}{l}\text { Global scholars still have argument on the focus of BRI and } \\
\text { major disputed elements of strategy, projects and significances. }\end{array}$ & $\begin{array}{l}\text { The Journal of } \\
\text { Contemporary China Studies }\end{array}$ \\
\hline Yu (2017) [34] & China focuses on BRI initiatives economically, politically, and strategically. & $\begin{array}{c}\text { Journal of } \\
\text { Contemporary China }\end{array}$ \\
\hline Djankov \& Miner (2016) [45] & $\begin{array}{l}\text { It provides a potential new channel like Century Maritime Silk Road } \\
\text { on the shipping networks and the development of hub seaports. }\end{array}$ & $\begin{array}{l}\text { Transportation Research } \\
\text { Part E: Logistics and } \\
\text { Transportation Review }\end{array}$ \\
\hline Wang et al. (2017) [46] & $\begin{array}{l}\text { The BRI has derived to epitomize China's growing significance } \\
\text { in international affairs, redesigning regional dynamics. }\end{array}$ & CEPN \\
\hline Sidaway \& Woon (2017) [47] & $\begin{array}{l}\text { The revival of a Silk Road(s) bears a history closely focused } \\
\text { European imperialism is adjoined about in the modern } \\
\text { adaptation of the notion into BRI chronicles. }\end{array}$ & Professional Geographer \\
\hline $\operatorname{Jian}(2017)[48]$ & BRI will form the backbone of future trade arrangements. & $\begin{array}{l}\text { Al Jazeera } \\
\text { Centre for Studies }\end{array}$ \\
\hline Shapiro (2017) [49] & $\begin{array}{l}\text { BRI includes amity and collaboration, frankness and inclusiveness, } \\
\text { communal erudition and common benefit. }\end{array}$ & Geopolitics \\
\hline Aris (2016) [50] & BRI covers almost all regions of Asia, Africa, and Eastern Europe. & $\begin{array}{l}\text { CSS Analyses in } \\
\text { Security Policy }\end{array}$ \\
\hline $\operatorname{HKTDC}(2016)[51]$ & $\begin{array}{l}\text { Analysis of six economic corridors in the BRI. } \\
\text { Key areas of co-operation are policy, finance and others. }\end{array}$ & $\begin{array}{l}\text { Hong Kong Trade } \\
\text { Development Council }\end{array}$ \\
\hline $\mathrm{Du}(2016)[52]$ & $\begin{array}{l}\text { Compare the BRI with the TPP, claiming the former to be the } \\
\text { Chinese version of globalization. }\end{array}$ & $\begin{array}{l}\text { The Chinese Journal of } \\
\text { Global Governance }\end{array}$ \\
\hline Tian (2016) [53] & $\begin{array}{l}\text { BRI is China's grand strategy encountering the U.S.'s TPP } \\
\text { promotion or rebalancing in Asia. }\end{array}$ & Voices \\
\hline Hsueh (2016) [54] & $\begin{array}{l}\text { The BRI would provide a great opportunity for the internationalization of } \\
\text { the Renminbi, since more trade and investment can be settled with Renminbi. }\end{array}$ & $\begin{array}{l}\text { Journal of Contemporary } \\
\text { East Asia Studies }\end{array}$ \\
\hline
\end{tabular}




\section{Continued}

Tian et al. (2016) [55]

Yang et al. (2016) [56]

Wolff (2016) [57]

$\mathrm{Xu}(2016)[58]$

Xue (2016) [59]

Hali et al. (2015) [60]

Haggai (2016) [61]

Yuqing (2016) [62]

Huang (2016) [63]

EIU (2015) [64]

Swaine (2015) [65]

Zimmerman (2015) [66]
Outward FDI of China has become economically important to touch international investment with a $50 \%$ annual growth rate.

The rail way infrastructure can connect China to Europe as an important part of the BRI initiative.

The Belt and Road initiative has focused on infrastructure expansion and regional collaboration by organizations, mostly with the development banks.

China impetuses to reach well-adjusted regional development between coastal and inland regions, and places a priority on investment by BRI Initiative.

BRI influences the foreign policy agenda of China from "keeping a low profile" to "proactively and enterprisingly striving for achievements".

The BRI has been planned by Chinese policy makers and their supporters as a game changer for the whole area.

BRI initiative has huge potential in promoting economic growth in the partner nations.

China plans to achieve political, financial and diplomatic objectives through the AIIB through enabling BRI approach and routing regional collaboration and incorporation.

BRI initiative aims to boost business and spread affluence across 60 -plus countries with more than 4 billion people by construction of essential infrastructure and enhancing financial and trade links.

BRI is not only focused a transformed, stronger and better harmonized push to enlarge China's inspiration to foreign, but also joined with an internal investment initiative.

The BRI offers great potential in major financial, political, social, and tactical dominions; it also offerings many risks and possible anxieties.

BRI has been designed to redesign the financial and political direction in Central Asia and the Asian Pacific region by stimulating a connection of trade ways, political collaboration, and social exchange.
China Economic Journal

Ecosystem Health and Sustainability

German

Development Institute

China Economic Review

Journal of Contemporary

East Asia Studies

Strategic Studies

World Journal of Social Sciences and Humanities

Chinese Political

Science Review

China Economic Review

The Economist Intelligence Unit Limited

China Leadership Monitor

Center on

International Cooperation

So many studies have been done by the researchers on BRI issues but most of them are on the policy issues of BRI initiatives [34] [67] [68]. Only few studies have been done on the background of the initiative, strategy, opportunities, challenges for implementation and implication for future of global development [61]. This study contributes to the ongoing debate on economic development prospect of BRI initiative through exploring the context of origin, strategy, challenges, risks and opportunities for economic development in the BRI region.

\section{Conclusion}

The study analyzes the SMART objectives and strategies of BRI for economic development of member countries. The study uses a systematic literature review to obtain the objectives. The article reveals that there is a potential impact of BRI on the economic development of its member countries. Some of the member countries are getting direct benefits from it and other countries are in the way of getting benefits through infrastructure development, trading, cultural exchanges and mutual political agreements. Economic corridors, seaport, roads and railway 
networks help to increase economic growth among the partner countries. Economic corridors are acting as a corridor of economic development through suitable infrastructure, energy, gas, oil and electricity, roads, railways and other related projects. The article suggests that all the member countries should need to utilize their resources and make an effective network for global peace and sustainable economic development under BRI initiative. This study contributes to the ongoing debate on economic development prospects of BRI initiative through exploring the economic context, strategy, challenges, risks and opportunities for regional economic development.

\section{Conflicts of Interest}

The authors declare no conflicts of interest regarding the publication of this paper.

\section{References}

[1] Sarker, M.N.I., Hossin, A., Yin, X. and Sarkar, M.K. (2018) One Belt One Road Initiative of China: Implication for Future of Global Development. Modern Economy, 9, 623-638. https://doi.org/10.4236/me.2018.94040

[2] Sarker, M.N.I., Hossin, M.A., Anusara, J., Chanthamith, B. and Kumar, N. (2018) Practices of Low Carbon Economy in China: Challenges and Opportunities for Economic Development. Low Carbon Economy, 9, 18-32. https://doi.org/10.4236/lce.2018.91002

[3] Cheong, I. (2017) International Logistics and Trade Assessment of the Economic Background of the OBOR. Journal of International Logistic and Trade, 15, 72-82. https://doi.org/10.24006/jilt.2017.15.2.004

[4] Sarker, M.N.I., Hossin, M.A., Hua, Y., Sarkar, M.K. and Kumar, N. (2018) Oil, Gas and Energy Business under One Belt One Road Strategic Context. Open Journal of Social Sciences, 6, 119-134. https://doi.org/10.4236/jss.2018.64011

[5] Sarker, M.N.I., Hossin, M.A., Hua, Y.X., Anusara, J., Warunyu, S., Chanthamith, B., Shah, S., et al. (2018) Low Carbon City Development in China in the Context of New Type of Urbanization. Low Carbon Economy, 9, 45-61. https://doi.org/10.4236/lce.2018.91004

[6] Casarini, N. (2016) When All Roads Lead to Beijing. Assessing China's New Silk Road and Its Implications for Europe. International Spectator, 51, 95-108. https://doi.org/10.1080/03932729.2016.1224491

[7] Li, Y., Bolton, K. and Westphal, T. (2016) The Effect of the New Silk Road Railways on Aggregate Trade Volumes between China and Europe. Working Papers on East Asian Studies 5284, 1-24.

[8] Sheu, J.B. and Kundu, T. (2017) Forecasting Time-Varying Logistics Distribution Flows in the One Belt-One Road Strategic Context. Transportation Research Part E: Logistics and Transportation Review, 117, 5-22. https://doi.org/10.1016/j.tre.2017.03.003

[9] Sarker, M.N.I., Rahman, M.Z., Cao, Q. and Xu, Z. (2019) Impact of Small Entrepreneurship on Poverty Alleviation and Sustainable Livelihood of Street Vendors. International Journal of Innovation and Applied Studies, 25, 1241-1254.

[10] Lim, T.W. (2018) The One Belt One Road Narratives. China and the World: Ancient and Modern Silk Road, 1, Article ID: 1850007. 
https://doi.org/10.1142/S2591729318500074

[11] Feng, D.H. and Liang, H. (2018) Omnipresent Economics: The Belt-and-RoadInitiative (BRI) Underpinning. China and the World: Ancient and Modern Silk Road, 1, Article ID: 1850002. https://doi.org/10.1142/S2591729318500025

[12] Khattak, A.K. and Khalid, I. (2017) China's One Belt One Road Initiative: Towards Mutual Peace \& Development. Journal of Research Society of Pakistan, 54, 1-20.

[13] Sarker, M.N.I., Wu, M., Alam, G.M. and Islam, M.S. (2019) Role of Climate Smart Agriculture in Promoting Sustainable Agriculture: A Systematic Literature Review. International Journal of Agricultural Resources Governance and Ecology, 15, 323-337. https://doi.org/10.1504/IJARGE.2019.104199

[14] Blanchard, J.M.F. and Flint, C. (2017) The Geopolitics of China's Maritime Silk Road Initiative. Geopolitics, 22, 223-245. https://doi.org/10.1080/14650045.2017.1291503

[15] Ferdinand, P. (2016) Westward Ho-The China Dream and "One Belt, One Road": Chinese Foreign Policy under Xi Jinping. International Affairs, 92, 941-957. https://doi.org/10.1111/1468-2346.12660

[16] Amin, M., Al Sarker, M.N.I., Hossin, M.A., Nasrin, M. and Huda, N. (2018) Cigarette Selling and Buying by the Minor and Adolescents in Bangladesh: Prevalence, Perceptions and Awareness. The Journal of Social Sciences Research, 4, 556-570. https://doi.org/10.32861/jssr.412.556.570

[17] Tianming, G. and Erokhin, V.L. (2017) One Belt One Road and Northern Sea Route: Perspectives and Risks for China to Participate. Collaboration between China and Russia: One Belt One Road Initiative, Moscow, 9, 15.

[18] Sarker, M.N.I. (2017) An Introduction to Agricultural Anthropology: Pathway to Sustainable Agriculture. Journal of Sociology and Anthropology, 1, 47-52.

[19] Sarker, M.N.I. and Jie, Z. (2017) Social Security for Vulnerable Groups in Bangladesh on Government Perspective: Contribution of Research Leader. Journal of Public Policy and Administration, 1, 1-9.

[20] Liu, C., Kuang, Y., Huang, N. and Liu, X. (2014) An Empirical Research on Evaluation of Low-Carbon Economy in Guangdong Province, China: Based on "Production, Life and Environment”. Low Carbon Economy, 5, 139-152. https://doi.org/10.4236/lce.2014.54015

[21] Fredriksson, C., Mubarak, F., Tuohimaa, M. and Zhan, M. (2017) Big Data in the Public Sector: A Systematic Literature Review. Scandinavian Journal of Public Administration, 21, 39-61.

[22] Sarker, M.N.I., Cao, Q., Wu, M., Hossin, M.A., Alam, G.M. and Shouse, R.C. (2019) Vulnerability and Livelihood Resilience in the Face of Natural Disaster: A Critical Conceptual Review. Applied Ecology and Environmental Research, 17, 12769-12785.

[23] Sarker, M.N.I. (2019) Instrumentally Rationalizing Public Administration. In: Farazmand, A., Ed., Global Encyclopedia of Public Administration, Public Policy, and Governance, Springer, Berlin, 1-5. https://doi.org/10.1007/978-3-319-31816-5_3861-1

[24] Uberoi, P. (2016) Problems and Prospects of the BCIM Economic Corridor. China Report, 52, 19-44. https://doi.org/10.1177/0009445515613868

[25] Zeng, Q., Wang, G.W.Y., Qu, C. and Li, K.X. (2017) Impact of the Carat Canal on the Evolution of Hub Ports under China's Belt and Road Initiative. Transportation Research Part E: Logistics and Transportation Review, 117, 96-107. https://doi.org/10.1016/j.tre.2017.05.009 
[26] PWC (2016) Opportunities in Emerging Market China: Belt \& Road, PPP.

[27] Muzakki, F. (2017) Examining China's Role in BRICS and One Belt One Road Initiative through English School Perspective. The Future of BRICS and the Future of Global Governance, Xiamen, 1-2.

[28] Duan, F., Ji, Q., Liu, B.Y. and Fan, Y. (2018) Energy Investment Risk Assessment for Nations along China's Belt \& Road Initiative. Journal of Cleaner Production, 170, 535-547. https://doi.org/10.1016/j.jclepro.2017.09.152

[29] Sarker, M.N.I., Hossin, M.A., Wu, M., Alam, G.M., Shafi, M., Pervez, A.K. and Rahman, A. (2018) Determinants and Pattern of Urbanization and Counter-Urbanization: The Case of South Asia. The Journal of Social Sciences Research, 4, 802-812.

[30] Hossin, M.A., Sarker, M.N.I., Xiaohua, Y. and Frimpong, A. N. K. (2018) Development Dimensions of e-Commerce in Bangladesh. Proceedings of the 2018 International Conference on Information Management \& Management Science, August 2018, 42-47. https://doi.org/10.1145/3277139.3277152

[31] Sarker, M.N.I., Wu, M., Shouse, R.C. and Ma, C. (2019) Administrative Resilience and Adaptive Capacity of Administrative System: A Critical Conceptual Review. Proceedings of the 13th International Conference on Management Science and Engineering Management, Ontario, 5-8 August 2019, 717-729. https://doi.org/10.1007/978-3-030-21255-1_55

[32] Kaplan, Y. (2017) China's OBOR as a Geo-Functional Institutionalist Project. Baltic Journal of European Studies, 7, 7-23. https://doi.org/10.1515/bjes-2017-0002

[33] Ejdys, J. (2017) New Silk Road-A Weak or a Strong Signal? Procedia Engineering, 182, 182-188. https://doi.org/10.1016/j.proeng.2017.03.159

[34] Yu, H. (2017) Motivation behind China's “One Belt, One Road” Initiatives and Establishment of the Asian Infrastructure Investment Bank. Journal of Contemporary China, 26, 353-368. https://doi.org/10.1080/10670564.2016.1245894

[35] Sarker, M.N.I., Islam, M.S., Ali, M.A., Islam, M.S., Salam, M.A. and Mahmud, S.M.H. (2019) Promoting Digital Agriculture through Big Data for Sustainable Farm Management. International Journal of Innovation and Applied Studies, 25, $1235-1240$.

[36] Muttarak, R. (2017) Potential Implications of China’s “One Belt, One Road” Strategies on Chinese International Migration.

http://pure.iiasa.ac.at/id/eprint/14556

[37] Jones, D.A. and Liu, H.Z. (2017) Management of Chinese Foreign Direct Investment: "One Belt, One Road" across Eurasia to Africa and Europe amidst Maritime Tensions in the South China Sea Region. International Relations and Diplomacy, 5, 486-500. https://doi.org/10.17265/2328-2134/2017.08.003

[38] Chung, C.P. (2017) What Are the Strategic and Economic Implications for South Asia of China's Maritime Silk Road Initiative? The Pacific Review, 31, 315-332. https://doi.org/10.1080/09512748.2017.1375000

[39] Liu, H.Q. (2017) The Security Challenges of the "One Belt, One Road” Initiative and China's Choices. Croatian International Relations Review, 23, 129-147. https://doi.org/10.1515/cirr-2017-0010

[40] Zeng, J. (2017) Does Europe Matter? The Role of Europe in Chinese Narratives of "One Belt One Road" and "New Type of Great Power Relations". Journal of Common Market Studies, 55, 1162-1176. https://doi.org/10.1111/jcms.12535

[41] Das, K.C. (2017) The Making of One Belt, One Road and Dilemmas in South Asia. 
China Report, 53, 125-142. https://doi.org/10.1177/0009445517696624

[42] Du, J. and Zhang, Y. (2017) Does One Belt One Road Initiative Promote Chinese Overseas Direct Investment? China Economic Review, 47, 189-205.

https://doi.org/10.1016/j.chieco.2017.05.010

[43] Vangeli, A. (2017) China's Engagement with the Sixteen Countries of Central, East and Southeast Europe under the Belt and Road Initiative. China \& World Economy, 25, 101-124. https://doi.org/10.1111/cwe.12216

[44] Gabuev, A. (2017) Crouching Bear, Hidden Dragon: “One Belt One Road" and Chinese-Russian Jostling for Power in Central Asia. The Journal of Contemporary China Studies, 5, 61-78. https://doi.org/10.1080/24761028.2016.11869097

[45] Djankov, S., Hendrix, C.S., Lawrence, R.Z., Miner, S., Truman, E.M. and Toohey, F. (2016) China's Belt and Road Initiative: Motives, Scope and Challenges. Peterson Institute for International Economics Briefing, (PIE Briefing 16-2), 1-34.

https://www.piie.com/publications/piie-briefings/chinas-belt-and-road-initiative-m otives-scope-and-challenges

[46] Wang, X., Ruet, J. and Richer, X. (2017) One Belt One Road and the Reconfiguration of China-EU Relations. Centre d'économie de l'Université, Paris, 1-17. https://hal.archives-ouvertes.fr/hal-01499020/document

[47] Sidaway, J.D. and Woon, C.Y. (2017) Chinese Narratives on "One Belt, One Road" in Geopolitical and Imperial Contexts. Professional Geographer, 69, 591-603. https://doi.org/10.1080/00330124.2017.1288576

[48] Jian, W. (2017) “One Belt One Road": A Vision for the Future of China-Middle East Relations.

http://studies.aljazeera.net/en/reports/2017/05/belt-road-vision-future-china-middl e-east-relations-170509102227548.html

[49] Shapiro, J.L. (2017) One Belt, One Road, No Dice. Geopolitics, Geopolitical Futures, 1-7. https://geopoliticalfutures.com/one-belt-one-road-no-dice/

[50] Aris, S. (2016) One Belt, One Road: China’s Vision of “Connectivity”. CSS Analyses in Security Policy No. 195, 1-4.

[51] HKTDC (2017) The Belt and Road Initiative: Country Profiles. HKTBC, 6, 1-4.

[52] Du, M.M. (2016) China's “One Belt, One Road” Initiative: Context, Focus, Institutions, and Implications. The Chinese Journal of Global Governance, 2, 30-43. https://doi.org/10.1163/23525207-12340014

[53] Tian, J. (2016) “One Belt and One Road”: Connecting China and the World. Voices, (June), 1-3.

https://www.mckinsey.com/industries/capital-projects-and-infrastructure/our-insig hts/one-belt-and-one-road-connecting-china-and-the-world

[54] Hsueh, C. (2016) Taiwan's Perspective on China's “One Belt, One Road” Strategy. Journal of Contemporary East Asia Studies, 5, 37-60. https://doi.org/10.1080/24761028.2016.11869096

[55] Tian, W., Yu, M. and Zhang, F. (2016) The Exceptional Performance of Chinese Outward Direct Investment Firms. China Economic Journal, 9, 209-219. https://doi.org/10.1080/17538963.2016.1172783

[56] Yang, D., Cai, J., Hull, V., Wang, K., Tsang, Y.-P. and Liu, J. (2016) New Road for Telecoupling Global Prosperity and Ecological Sustainability. Ecosystem Health and Sustainability, 2, e01242. https://doi.org/10.1002/ehs2.1242

[57] Wolff, P. (2016) China's “Belt and Road” Initiative-Challenges and Opportunities. German Development Institute, Bonn. 
https://www.die-gdi.de/uploads/media/Belt_and_Road_V1.pdf

[58] Xu, H. (2016) Domestic Railroad Infrastructure and Exports: Evidence from the Silk Route. China Economic Review, 41, 129-147. https://doi.org/10.1016/j.chieco.2016.09.005

[59] Xue, L. (2016) China's Foreign Policy Decision-Making Mechanism and "One Belt One Road” Strategy. Journal of Contemporary East Asia Studies, 5, 23-35. https://doi.org/10.1080/24761028.2016.11869095

[60] Hali, S.M., Shukui, T. and Iqbal, S. (2015) One Belt and One Road: Impact on China-Pakistan Economic Corridor. Strategic Studies, 34, 147-164.

[61] Haggai, K. (2016) One Belt One Road Strategy in China and Economic Development in the Concerning Countries. World Journal of Social Sciences and Humanities, 2, 10-14.

[62] Xing, Y. (2016) The Asian Infrastructure Investment Bank and China's Role in Regional Economic Governance. East Asian Policy, 8, 25-36. https://doi.org/10.1142/S1793930516000179

[63] Huang, Y.P. (2016) Understanding China's Belt \& Road Initiative: Motivation, Framework and Assessment. China Economic Review, 40, 314-321. https://doi.org/10.1016/j.chieco.2016.07.007

[64] EIU (2015) Prospects and Challenges on China's “One Belt, One Road”: A Risk Assessment Report. http://www.eiu.com

[65] Swaine, M.D. (2015) Chinese Views and Commentary on the "One Belt, One Road" Initiative. China Leadership Monitor, 47, 3-27. https://www.hoover.org/sites/default/files/research/docs/clm47ms.pdf

[66] Zimmerman, T. (2015) The New Silk Roads: China, the U.S. and the Future of Central Asia. Center on International Cooperation, (October), New York, 1-26.

[67] Kudaibergenova, D.T. (2017) "My Silk Road to You”: Re-Imagining Routes, Roads, and Geography in Contemporary Art of "Central Asia." Journal of Eurasian Studies, 8, 31-43. https://doi.org/10.1016/j.euras.2016.11.007

[68] Hu, R., Liu, R. and Hu, N. (2017) China's Belt and Road Initiative from a Global Health Perspective. The Lancet Global Health, 5, e752-e753. https://doi.org/10.1016/S2214-109X(17)30250-4 